Acta Poloniae Historica

110,2014

PL ISSN 0001-6892

Tatyana Tairova-Yakovleva

\title{
THE ROLE OF THE RELIGIOUS FACTOR \\ AND PATRIARCH NIKON \\ IN THE UNIFICATION OF UKRAINE AND MUSCOVY
}

\begin{abstract}
The reasons of the unification of Ukraine and Muscovy in 1654 are of great importance for historians. The judicial nature of the union has been the topic of various discussions and polemics. A detailed study of the issue was done by J. Bassarab in 1982. ${ }^{1}$ The modern Ukrainian historiography has done a lot in studying Khmelnytsky's reasons for choosing Muscovy's tsar. In this essay, I focus on another issue: What was the main reason for Tsar Aleksei Mikhaulovich to take Ukraine under his 'high hand'? Did he actually think about a 'reunification' or 'gathering of the Rus' lands' (these ideas being quite popular in Russian historiography)? What was the role of the religious factor, Russian Orthodox Church and, particularly, Patriarch Nikon in the tsar's decision? Why did Muscovy break the Polyanovka Treaty with Polish-Lithuanian Commonwealth and started a war for Ukraine?
\end{abstract}

Keywords: Patriarch Nikon, Treaty of Pereyaslav, Muscovy, Ukraine, Bohdan Khmelnytsky

The famous Russian historian Sergeĭ Solov'ëv used for the Muscovite-Ukrainian union in 1654 the term 'annexation' (prisoedinenie - literally, 'adhesion'). Solov'ëv considered that the main reason for the tsar to take Ukraine under his 'high hand' was his fear that Khmelnytsky might join with the Turks. In that case, the Ottoman realm would reach the Muscovite frontiers. ${ }^{2}$ Another Russian Empire historian Nikolaĭ Kostomarov, a former political prisoner and man of considerable self-censorship, shares these views. He also viewed the Turkish issue as the tsar's main motivation and used the term

${ }^{1}$ John Bassarab, Pereiaslav 1654: A Historiographical Study (Edmonton, 1982).

${ }^{2}$ Sergeř Solov'ëv, Istoriya Rossii s drevneishikh vremën, in idem, Sochineniya, 18 vols. (Moscow, 1993-8), x (6), 561. 
'uniting'. ${ }^{3}$ At the beginning of the twentieth century, K.V. Kharlampovych, in his brilliant study of Russian-Ukrainian Church relations, wrote: "Religious motivations were brought to the forefront in all B. Khmelnytsky's negotiations with Moscow." ${ }^{4}$ It is quite clear why Soviet historiography ignored the religious factor of the union. But it seems strange that none of the pre-revolutionary historians noticed Nikon's involvement in the events of 1653-4. Even in the best studies of Nikon's rule we will not find any mentioning of the patriarch's role in the unification of Ukraine. ${ }^{5}$

The great Ukrainian historian Mykhailo Hrushevskyi believed that religious motives were only a mask for Khmelnytsky. Hrushevskyi used the term 'protectorate' and could identify no source that would explain Moscow's motivation for the union whatsoever. ${ }^{6}$

Notably, however, none of these famous historians referred to a 'gathering of lands' or reunification. It should also be noted that all these historians (even Solov'ëv) paid little attention to the reasons why tsar Alekseĭ Mikhailovich decided to take the Zaporozhian Host 'under his hand'. They all were much more interested in Khmelnytsky's incentives. This gap in the research was quite artfully exploited by Soviet propaganda. The paradigm of 'reunification' firmly replaced Sergei Solov'ëv's older term, 'annexation'.

In the early 1930s, Stalin established a 'patriotic' attitude towards history in the Soviet Union. His famous letter to the editor of the journal Proletarskaya revolutsiya [The Proletarian Revolution] ${ }^{7}$ was the starting-point for these new conceptions. After that, all of history was subject to revision, including the history of Ukraine. As a result, a new paradigm of 'reunification of Ukraine and Russia' and 'unification' of two 'brother-nations' became commonplace.

${ }^{3}$ Nikolaĭ I. Kostomarov, Bogdan Khmel'nitskiŭ (Moscow, 1994), 636.

${ }^{4}$ Kostiantyn Kharlampovych, Malorossiǔskoe vliyanie na velikorusskuyu tserkovnuyu zhizn' (Kazan, 1914).

${ }^{5}$ Nikolă Kapterev, Patriarkh Nikon i tsar Aleksě Mikhaŭlovich (Moscow, 1996); Boris A. Uspenskiı̌, Tsar' $i$ patriarkh. Kharizma vlasti $v$ Rossii. Vizantǐ̌skaya model' i eё russkoe pereosmyslenie (Moscow, 1998).

${ }^{6}$ Mykhailo Hrushevs'kyĭ, Istoriya Ukrayiny-Rusy, 11 vols. (Kiev, 1991-8), ix, pt. 2, pp. 610-11.

${ }^{7}$ Joseph V. Stalin, 'Some Questions Concerning the History of Bolshevism: Letter to the Editorial Board of the Magazine "Proletarskaya Revolutsiya", in idem, Works, xiii (Moscow, 1955), 84-104. 
This new conception was presented for the first time in the 'instructions' for a new history textbook, which announced the positive influence of 'the reunion'. ${ }^{8}$ In 1951, the eminent historian Militsa Nechkina wrote a letter to the editor of the journal Voprosy istorii, stressing the extremely positive role of reunification. ${ }^{9}$ Her letter initiated an all-Union 'discussion', which finally enshrined the idea that Ukrainians had fought for 'a hundred years' to reunite with the 'brotherly Russians'. And after 1654, the two nations continued their joint fight against foreign aggression and local capitalists. ${ }^{10}$

Stalin's death did not change anything: Soviet historians continued by enthusiastically celebrating the 300th anniversary of the 'reunification' in 1954. An amazing example is the headings featured in the document collection Vossoedinenie Ukrainy s Rossiě, all of which refer to 'the reunification', with no specific mention about it in the content of any of these documents.

During the whole Soviet period both Ukrainian and Russian historians used the term vossoedinenie, referring to the unification of 'brotherly nations' and of the land of former Rus'. The idea of union of 'two brother' nations is still very strong among some modern Russian historians. This could be explained both by their imperial ambitions and by their poor knowledge of Ukrainian history. For example, Igor' Andreev actually believes that Aleksei Mikhaílovich considered "the Orthodox lands in the Polish-Lithuanian Commonwealth as belonging to him by law, the property of the Grand Princes of Vladimir." ${ }^{11}$ Aleksei Shkvarov, in his recent work, describes the 'return of Russian land' as Alekseî Mikhaillovich's only reason for taking 'Little Russia' under his hand. ${ }^{12}$ Neither of these historians is able to make any references to the documents.

The study of identity and national memory in mid-seventeenth century Ukraine shows that there were only dim recollections of Kievan Rus'. ${ }^{13}$

${ }^{8} \mathrm{~K}$ izucheniyu istorii (Moscow, 1938).

${ }^{9}$ Militsa V. Nechkina, 'K voprosu o formule "naimen'shee zlo"', Voprosy Istorii, 4 (1951), 44-8.

${ }^{10}$ Alekseĭ I. Baranovich (ed.), Vossoedinenie Ukrainy s Rossiě 1654-1954. Sbornik statě (Moscow, 1954), 5.

${ }^{11}$ Igor'Andreev, Aleksě Mikhaǐlovich (Moscow, 2003), 233.

12 Alekseĭ G. Shkvarov, Petr I i kazaki (Sankt-Peterburg, 2010), 110.

13 Tatyana G. Yakovleva (Tairova), 'Ukrainskaya shlakhta i gosudarstvennaya ideya v gody osvoboditelnoĭ voĭny', in Valeriı̌ A. Smoliı̌ (ed.), Natsional'no-vyzvol'na 
Orthodox unity existed, but it did not prevent Ukrainian Cossacks from participating in campaigns against Muscovy at the beginning of the seventeenth century. Religious unity with Danubian Principalities also existed, but it did not prevent quarrels and military clashes, either.

The major modern study of Bohdan Khmelnytsky's period was done by Ukrainian historians V.A. Smolǐ and V.S. Stepankov. ${ }^{14}$ Again, they would not discuss the reasons why Moscow decided on annexation of Ukraine, and neglected Nikon's role in it. They were only interested in Ukraine's position and the form of the MuscoviteUkrainian union. The same is true for another study, by V.A. Smolii and V.S. Stepankov, published in the well-known series Ukrayina kriz' viky [Ukraine through centuries]; as we can read there, "After long and difficult negotiations, the Zemsky Sobor made the decision" about Ukraine. Nothing about details, or the role of Nikon, once again. ${ }^{15}$

Another modern Ukrainian historian Taras Chukhlib, in his study of Ukrainian foreign policy, avoids dealing with Moscow's reasons for the union, nor does he even mention the name of Nikon. ${ }^{16}$ The most detailed study of the relation between Ukraine and the tsar's family before and after the Pereyaslav Agreement was carried out by V. Horobets. He explains Moscow's decision by the idea of 'Third Rome' and, particularly, by the ideas of the elder Arsenii. ${ }^{17}$ Horobets observes that Nikon added 'the Little Russia' to his title of Patriarch of Rus' 'too hastily', ${ }^{18}$ yet he does not see any other aspect of Nikon's role in the unification of Muscovy and Ukraine whatsoever.

A Canadian historian O. Subtelny, in his history of Ukraine, explains the Russian move by the fear of possible Ukrainian union with the Turks. ${ }^{19}$ Similar view is shared by W. Serczyk, who also emphasises

viüna ukrayins'kogo narodu seredyny XVII stolittya. Polityka, ideologiya, viǔs'kove mystetstvo (Kiev, 1998), 131-41.

${ }^{14}$ Valeriǔ Smoliǔ and Valerij Stepankov, Bogdan Khmel'nyts'kyĭ. Sotsial'nopolitychnyı portret (Kiev, 2009).

${ }^{15}$ Iidem, Ukrayins'ka natsional'na revolyutsiya XVII st. (1648-1676 rr.) (Ukrayina kriz' viky, 7, Kiev, 1999), 124.

${ }^{16}$ Taras Chukhlib, Get'many $i$ monarkhy. Ukrayins'ka derzhava $v$ mizhnarodnykh vidnosynakh 1648-1714 rr. (Kiev and New York, 2003).

${ }_{17}$ Elder Arseniǐ (Arseniı̌ Sukhanov), the elder of the Trinity-Sergius Monastery, was a Russian Orthodox theologian and religious leader.

18 Viktor Horobets [Gorobets], Volymo tsarya skhidnogo... Ukrayins'kiu Get'manat ta rosiǔs’ka dynastiya do i pislya Pereyaslava (Kiev, 2007), 48-9.

19 Orest Subtelny, Ukraine: A History (3rd edn., Toronto, 2000), 134 ff. 
the role of the religious factor for Khmelnytsky. ${ }^{20} \mathrm{~A}$. Kappeler observes the change in Muscovy's policy in 1653, but would not explain why this change occurred. ${ }^{21} \mathrm{~J}$. Kaczmarczyk was inclined to explaining the tsar's decision by the Cossack's military successes over the Polish-Lithuanian Commonwealth. ${ }^{22}$ T. Hodana studied the image of Moscow in the eyes of the Orthodox Ukrainians - which is the other side of the coin that the present article tries to seek. ${ }^{23}$ S. Plokhiu in his works stressed the religious factor in all official Muscovite documents, concerning the unification of Ukraine, but he has not specifically studied the role of Nikon. ${ }^{24}$ Similarly to T. Hodana, Plokhir mainly studies the religious motives in the MuscoviteUkrainian relations from the Cossacks side. ${ }^{25}$ Hence, neither the older nor the modern historiography has yet given an explanation of Tsar Aleksel Mikhaillovich's reasons for the unification with Ukraine.

Let us begin with the terms used in official Muscovite texts in 1653-4. On 11 (1) October 1653, the Zemsky Sobor (Assembly of the Land) made the decision to take Bohdan Khmelnytsky and the Zaporozhian Host under the tsar's 'high hand'. Preventing "the eradication of the Orthodox Christian religion and the destruction of God's holy churches" by the Poles ${ }^{26}$ was the only reason why the tsar "agreed to take under his high hand Bohdan Khmelnytsky and the entire Zaporozhian Host with all their lands", ${ }^{27}$ according to the Assembly's official decision. This official act mentions no 'reunion', gathering of lands, and even no Malaya Rossiya. The population of Ukraine was

${ }^{20}$ Władysław Serczyk, Historia Ukrainy (Wrocław, 1997), 130-1.

${ }^{21}$ Andreas Kappeler, Kleine Geschichte der Ukraine (Munich, 1994) (I have used the Ukrainian transl., Mala istoriya Ukrayiny [Kiev, 2007], 56-7).

22 Janusz Kaczmarczyk, Bohdan Chmielnicki (Wrocław, etc., 1988), 200-1.

23 Tomasz Hodana, Między królem $i$ carem. Moskwa $w$ oczach prawosławnych Rusinów - obywateli Rzeczypospolitej (na podstawie piśmiennictwa końca XVI - połowy XVII stulecia) (Studia Ruthenica Cracoviensia, 4, Cracow, 2008).

${ }^{24}$ Sergiı̌ Plokhǐ [Serhii Plokhy], 'Pereyaslav 1654: Pravoslavny dyskurs ta politychna kul'tura', in Pavlo Sokhan' et al. (eds.), Pereyaslavs'ka Rada 1654 roku (Istoriografiya ta doslidzhennya) (Kiev, 2003), 782-3; Sergiı̌ Plokhiŭ, 'Kryla protektsyiyi: do vyznachennya pravovogo zmistu Pereyaslavs'koyi ugody 1654 roku', Mediaevalia Ucrainica: Mental'nist' ta Istoriya Idě̆, 4 (1995), 78-80.

${ }^{25}$ Idem, The Cossacks and Religion in Early Modern Ukraine (New York, 2001).

${ }^{26}$ Panteleĭmon P. Guzdenko et al. (eds.), Vossoedinenie Ukrainy s Rossiel. Dokumenty $i$ materialy, 3 vols. (Moscow, 1954), iii, 411.

27 Ibidem, iii, 413. 
called Cherkasians, without any mention of rusiny, rus'kie, or any reflection on their unity with 'Russians' (meaning, subjects of Muscovy). The tsar was taking Khmelnytsky, the Zaporozhian Host and "all Orthodox people" with "their cities and lands" under his protection. ${ }^{28}$ Among references to the 'old times' in all these documents one only finds "previous rights and liberties, which had been given to Ruthenians by the Lithuanian grand dukes and Polish kings." 29

The same reasons were named in official statements of the Muscovite government during Muscovite-Polish negotiations. These documents name Khmelnytsky and Ukrainians 'Zaporozhian Cherkasy', 30 or subjects of the Polish king. Among the charges against the PolishLithuanian Commonwealth are references only to religious persecution, not a single word being said concerning, for instance, the return of 'hereditary lands'.

Thus, the only reason that appears in the tsarist official documents was the need to take Ukraine under the tsar's protection because Alekseî Mikhaulovich was worried about the Orthodox population. It was not merely a pretext. The same reason was declared in the tsar's appeal of April 1654 to the Orthodox citizens of the Grand Duchy of Lithuania. Starting the war, the monarch announced that his goal was to protect the Orthodox Church from religious persecutions. ${ }^{31}$

The only exception was the speech of Buturlin in Pereyaslav, in which he mentioned Prince Vladimir, and Kiev as the old capital of the princes, and used the allegory of the eagle (Muscovy) that covers the nestlings (Ukraine) with his wings. Not an official document, this text was written as an address to Cossack leaders. I would agree with S. Plokhil that in this particular case the Muscovite envoy used "elements of the Ukrainian cultural code" and tried to speak with Cossack leaders in their language. ${ }^{32}$ Moreover, it is possible that this speech was prepared by some Kiev theologian who worked in Moscow (Epiphaniǐ Slavinetskiǐ or Arseniǐ Satanovskiǐ).

28 Ibidem, 468.

29 Ibidem, 568.

${ }^{30}$ Ibidem, 267-75.

${ }^{31}$ Boris N. Florya, Russkoe gosudarstvo $i$ ego zapadnye sosedi (1655-1661 gg.) (Moscow, 2010), 9; Antoni Mironowicz, Prawosławie $i$ unia za panowania Jana Kazimierza (Białystok, 1997), 128.

32 Plokhǐ̌, 'Pereyaslav 1654', 784-6; idem, 'Kryla protektsyiyi', 80-2. 
The tsar was a highly religious man, interested in theological arguments and discussions. But there may have been other reasons to support Khmelnytsky. Was it a fear of Turkish aggression (as Solov'ëv and Kostomarov insisted)? Possibly, yes. But the threat of a Ukrainian-Ottoman alliance had existed long before 1653; from 1648 onwards at the very least, and this had not forced the tsar to accept Khmelnytsky then.

After a few years of conflicts, in 1659, the Zaporozhian Host once again accepted the tsar as their sovereign. In the official statements of Muscovite authorities, there was no mention of 'reunion', 'gathering of lands' or 'returning the former Kievian Rus' territories'. Aleksei Mikhailovich was concerned about regaining Ukraine (those were the years of his conflict with Nikon, and the tsar's political success would represent a very important sign of God's blessing). He even arranged public worship in the apostolic cathedral and asked the diak to read an official speech, explaining how "God brought the Malyi-Rossiǔskiu Zaporozhian Host under the high hand of the great sovereign." 33 Again, there was no reference made to former times.

Now, let us focus on the 'gathering of lands' concept. Those historians who offer this particular reason for the tsar's conduct refer to the statement of Ivan III that declared acquisition of all Kievan Rus' lands as his objective. Yet, by the mid-seventeenth century the situation had turned totally different and the political strategy was also different. Practical actions and statements of Alekseĭ Mikhaŭlovich's government show that Ukraine was not their main territorial goal. For Moscow, the Zaporozhian Host was a military tool for expansion into White Rus' and for regaining Smolensk. The events of the Muscovite-Polish war came as evidence of this.

The tsar's first step after the 1654 union was to start a war against the Polish-Lithuanian Commonwealth. With the help of the Ukrainian Cossacks, Muscovite troops during 1654-5 took over Smolensk and most of White Rus'. Alekseĭ Mikhaulovich considered this campaign of such importance that he decided personally to take part in it. By contrast, he did not direct the campaign against Volhynia or Voivodeship of Rus' (centred in Lvov). Hence, he was not as much interested in the former Halych Rus' lands, but made attempts to gain back the

${ }_{33}$ Moscow, Rossiǔskiı̌ Gosudarstvennyı̆ Arkhiv Drevnikh Aktov (hereinafter: RGADA), F. 229, op. 1, no. 44, 1. 490. 
territories that had been lost by Muscovy during the Time of Troubles, through the Truce of Deulino and the Treaty of Polyanovka.

Beside the Smolensk region, the tsar was highly interested in White Rus'. This was the reason for the keen conflict between the Cossack hetman's administration and Muscovite voivodes about who would actually govern the White Rus' lands (Bykhov and Mogilev districts). The conflict had already started in 1655, right after the 'liberation' of White Rus'. The final result was tragic and bloody. Muscovite troops in 1659 took over Old Bykhov, which was defended by Ukrainian Cossacks, hanged many of their officers and sent the rest of them to Siberia. ${ }^{34}$ The new Pereyaslav treaty of 1659 gave White Rus' over to the tsar's authority and prohibited the hetman's administration from interfering with it. Patriarch Nikon described this campaign thus: "by God's help and our blessing we were victorious over Lithuania." 35 There was no reference to Kievan Rus'.

During the negotiations in Pereyaslav, Muscovite voivodes also tried to get some Ukrainian territory under their direct control. Muscovite commander Alexander Trubetskoĭ told hetman Yuriǔ Khmelnytsky that Novhorod Severs'kyı̆, Chernihiv, Starodub and Pochep should be under the rule of Muscovite voivodes, not under Cossack administration, as "those cities from the old times belonged to the Muscovite state, not to Malaya Rossiya." 36 This declaration is quite interesting. The tsar's representative refers not to the times of Kievan Rus', but to the much more recent Muscovite tsardom. It appears that in Muscovy, they were not quite sure about the borderline of Malaya Rus' and tried to exclude the whole Seversk land region from it.

Again, one can identify the tsar's priorities: in the future, Muscovy would never give up the Smolensk district to the Poles (by the terms of Andrusovo Truce, 1667, and the Eternal Peace Treaty of 1686), and would never agree to Ukrainian administration in White Rus'.

By the end of 1655, Vasiliǐ Buturlin's Muscovite regiment took part in Khmelnytsky's campaign towards western Ukrainian lands, Podolia

34 Tatyana Yakovleva (Tairova), Ruyina Get'manshchyny. Vid Pereyaslavs'koi rady -2 do Andrusivs'koyi ugody (Kiev, 2003), 32-3.

${ }^{35}$ Zapiski otdeleniya russkoŭ $i$ slavyanskŏ arkheologii imperatorskogo russkogo arkheologicheskogo obshchestva, 4 vols. (Sankt Petersburg, 1851-87), ii, 513.

${ }^{36}$ Akty, otnosyashchiesya $k$ istorii Yuzhno $i$ Zapadno ̌ Rossii, sobrannye $i$ izdannye Arkheograficheskoyu komissieyu, 15 vols. (Sankt Petersburg, 1846-92), iv, 261. 
and Halych Rus' ${ }^{37}$ The campaign showed that this part of Ukraine was of little interest to Moscow. The regiment returned home right after the unsuccessful sieges of Kamenets Podolskil and Lvov. For Khmelnytsky, this campaign was intended rather as military support for his new ally, the Swedish king. For the Muscovites, it was merely a burdensome duty enforced by the Pereyaslav Agreement.

Even later, Ukrainian lands were not to become a priority for Muscovite expansion. After a military defeat by the Poles in 1660 , Moscow dramatically changed its foreign policy. Now its obligations towards the Zaporozhian Host were to be measured against its military achievements in the Grand Duchy of Lithuania. The Boyars' Council in 1662 had to decide which territories they were ready to give up in order to earn peace with the Polish-Lithuanian Commonwealth. In the official proposal to the Poles, the boyars agreed to fix the border along the Dnieper and Dvina Rivers, retaining Vitebsk, Polotsk, Bykhov, Kiev and Zaporozhye. ${ }^{38}$ But they were ready "to split Cherkasy" - that is, Ukraine. ${ }^{39}$ In October 1662, the head of Muscovite foreign policy Afanasii Ordin-Nashchokin received instructions from the Chancellery of Privy Affairs. If the Poles would not have agreed to split Ukraine, these instructions allowed Ordin-Nashchokin " to swear that yet another part [of Ukraine] will be given to them, as soon as there were negotiations between the tsar's great envoys and the king's commissars." 40 Nashchokin himself insisted that giving up the whole of Ukraine might gain Russia the Smolensk and Seversk lands. ${ }^{41}$ Alekseĭ Mikhaillovich and the boyars did not agree: they wanted to keep the Left-Bank Ukraine, and as a last compromise, they were ready to give up Kiev. ${ }^{42}$ Even the capital of the Old Rus' was less important to the tsar than Smolensk. It may sound unbelievable for supporters of the 'two brothers' theory, but archival documents do prove it. The above observation is also confirmed by the eminent Russian historian Boris Florya, who in one of his latest books concludes that, after the defeat of 1660, the Muscovite

37 Tatyana Yakovleva (Tairova), Get'manshchyna $v$ drugiu polovyni 50-kh rokiv XVII stolittya. Prichiny $i$ pochatok Ruyiny (Kiev, 1998), 156-65.

${ }^{38}$ RGADA, F. 79. 1666, no. 5, 1. 23.

${ }^{39}$ Ibidem, 1. 39.

40 RGADA, F. 27, no. 128-I, 1. 19-20.

${ }^{41}$ RGADA, F. 79. 1666, no. 3, 1. 242.

${ }^{42}$ Ibidem, no. 5, 1. 242. 
government was willing to defend its positions in White Rus', "but in fact gave up Ukraine."43

Later events confirm this point. In 1678, Muscovite troops abandoned Chyhyryn, giving up the southern part of the Right-Bank Ukraine to pro-Ottoman Cossacks. When in 1706 the then-Russian protégé, Hetman of Left-Bank Ukraine Ivan Mazepa re-established his control over the Right-bank area and reinstalled Cossack administration there, Peter I preferred to return the territory to the Poles in order to gain the Finnish and Baltic lands. Moscow's priorities in both cases were far away from old Kievan Rus'.

The time of Peter the Great is another part of Russian history, and its territorial demands depended on the needs of the new empire. Peter was not a religious man. In Alekser Mikhaĭlovich's era, religion played quite a different role. All that we have said about the tsar's priorities in territorial expansion is not to deny the religious factor. Both Seversk and Smolensk were Orthodox lands, where the Orthodox population was in much worse condition compared to Ukrainians after Khmelnytsky's uprising. There were suffering Orthodox territories also in the Danubian Principalities and Greece. The tsar simply could not help everybody at once, and had to establish priorities.

Therefore, Alekseĭ Mikhălovich used religious rhetoric to justify the annexation of Ukraine. His political goal was to gain back the territories that had been lost by Muscovy at the beginning of the seventeenth century (without any reference to the times of Kievan Rus'). And the idea of the 'Third Rome' was already quite popular among the tsar's entourage. Was the religious motivation just a mask (as Hrushevskyı thought), or was the tsar actually concerned about the Ukrainian Orthodox population?

Genuine religious motives were not unusual in the early modern era. Protecting Orthodox churches might seem a natural concern for an Orthodox sovereign. But there were serious conflicts that had existed between Muscovite and Ukrainian Orthodox Churches in the first half of the seventeenth century. Those problems have been recently studied quite thoroughly by Viktor Zhivov and Andreĭ Bulychev. ${ }^{44}$ After the terrible Time of Troubles, in which Cossacks took

${ }^{43}$ Florya, Russkoe gosudarstvo, 596.

${ }^{44}$ Andre ̌ A. Bulychev, Istoriya odno ̀ politicheskő̌ kompanii XVII veka: Zakonodatel'nye akty vtoro ̌ poloviny 1620-kh godov o zaprete svobodnogo rasprostraneniya 
an active part, a negative view of Ukrainians remained among the elites of Muscovy, both ecclesiastical and secular. In 1620, Patriarch Filaret (the father of the first Romanov tsar) forced the Holy Council (Sobor) to establish a law, requiring that all Orthodox Ukrainians, coming to Muscovy from Poland and Lithuania, had to be 're-baptised' (by triple immersion in water rather than having water poured over them). ${ }^{45}$ In 1627 Filaret launched new persecutions against Ukrainian Orthodoxy. Books printed in Ukraine and White Rus' were confiscated in Muscovite churches and monasteries. Many of them were thrown into fire by an executioner. However, by the end of 1630s, after the Smolensk war and death of Patriarch Filaret, the situation changed.

In the late 1640s a clerical group, 'the Zealots of piety' (revniteli blagochestiya) was formed in Muscovy; they insisted on reforms in the Muscovite Church. After the political crisis of 1648, the young tsar Alekseî Mikhaulovich was ready to agree with them.

Now we come to one of the key figures of our story - Paisios, the patriarch of Jerusalem. It is believed that he was an extremely talented preacher and a man of great intelligence. At the very least, he had great influence on three outstanding figures: Bohdan Khmelnytsky, Alekser Mikhaullovich and Nikon. In a certain sense, he was able to change their minds.

The first episode is well-known from the work of M. Hrushevs'kyl, who proved that Paisios had completely changed Khmelnytsky's mind and turned 'the tsar's ruler' into an independent sovereign. ${ }^{46}$ Modern Ukrainian historians V. Smolii and V. Stepankov also consider that his meeting with Paisios changed all of Khmelnytsky's goals. ${ }^{47} \mathrm{He}$ realised that he was a 'Prince of Rus", defending the holy Orthodox Church. ${ }^{48}$

Sergeĭ Lobachev, in his excellent biography of Nikon, ${ }^{49}$ first noticed the role of Paisios, patriarch of Jerusalem, in Alekseĭ Mikhaĭlovich's

'litovskikh' pechatnykh i rukopisnykh knig v Rossii (Moscow, 2004); Viktor Zhivov, Iz tserkovnol̆ istorii vremen Petra Velikogo. Issledovaniya i materialy (Moscow, 2004).

${ }^{45}$ Kharlampovych, Malorossiǔskoe vliyanie, 22.

${ }^{46}$ Hrushevs'ky̌̆, Istoriya Ukrayiny, viii, 125-7.

47 Smoliı̌ and Stepankov, Bohdan Khmel'nytsky̆, 208-9.

${ }^{48}$ Jakuba Michałowskiego wojskiego lubelskiego a później kasztelana bieckiego Księga pamiętnicza $z$ dawnego rękopisma będącego wtasnością Ludwika hr. Morsztyna, ed. Antoni Z. Helcel (Zabytki z Dziejów, Oświaty i Sztuk Pięknych, 2, Cracow, 1864), ii, 369-85.

${ }^{49}$ Sergeĭ V. Lobachev, Patriarkh Nikon (Sankt Petersburg, 2003). 
decision to promote Nikon. Lobachev discovered this by studying the Greek Acts in the Russian State Archive of Ancient Acts (RGADA). Unfortunately, this brilliant study is still unknown to Ukrainian historians, or at least not used by them. So, historians have been unable to combine 'the two sides of the coin', meaning Ukrainian and Russian occurrences.

Accompanied by the Cossack colonel Syluian Muzhylovsky, Paisios arrived in Moscow from Kiev, after his discussions with Khmelnytsky. Soon, he had an official meeting with the tsar. Moscow Patriarch Iosif and then-Archimandrite Nikon also attended the meeting. A few days later, Paisios wrote a letter to Aleksei Mikhaillovich, in which he paid many compliments to Nikon, saying that he "liked the discussion with him". ${ }^{50}$ Meanwhile, in Moscow, Paisios suggested that he planned to liberate the Holy Sepulchre and predicted that Alekseĭ Mikhaĭlovich would become the 'new Emperor Konstantine'. ${ }^{51}$ But, the first step was to deliver the Ukrainian Orthodox population from the PolishCatholic oppression. Most historians who study the history of the Ukraine are not aware of these far-reaching plans of Paisios.

Lobachev believes that the discussions with Paisios had a strong impact both on the tsar and the future patriarch. Paisios presented great plans. Even when heard through an interpreter, his speeches had a great impact. Meetings with the patriarch of Jerusalem had a great influence on the entire Muscovite foreign policy. In 1648-9, Moscow was highly suspicious of Khmelnytsky and his uprising. When Muzhylovsky asked for military support, the reply was quite categorical: a Christian sovereign cannot break his oath (meaning the tsar's peace treaty with the king of Poland). But after the meeting with Paisios, protection of the Orthodox Ukraine became a strategic goal for Tsar Alekseǐ Mikhaĭlovich.

Lobachev proved as well that Paisios had helped not only Nikon's career but also the whole 'Zealots of piety' group and noticed that Nikon's role in the unification of Ukraine with Muscovy had not yet been studied. ${ }^{52}$ Discussions with the Greek hierarchy convinced Alekseî Mikhaulovich of the need for Church reforms. These reforms were closely related to the reforms of Kievan

\footnotetext{
${ }^{50}$ Ibidem, 83.

${ }^{51}$ Ibidem, 84.

52 Ibidem, 84-5, 130.
} 
Metropolitan Petro Mohyla. It is quite significant that in Nikon's time, over 60 per cent of books collected in the patriarch's library (1,297 volumes in total) were foreign, including 20 per cent (249) Ukrainian books. ${ }^{53}$

Explaining Moscow's position in the years 1649-53, S. Plokhil wrote that "the tsar, as a Christian ruler, could not violate his oath to another Christian monarch". Later, when "the tsarist government began to feel more sure of itself and the impending war with the Commonwealth was made part of the state policy agenda", Moscow changed its approach to the justification of a war. ${ }^{54}$ But we cannot see any changes in Muscovy between 1649 and 1653 that were serious enough to justify this volte-face. It was instead a mental change, in which religious motives played an important part.

Kostomarov thought that Nikon had opposed the tsar's decision to support the Cossacks and to start the war against the Polish-Lithuanian Commonwealth. ${ }^{55}$ Actually, many documents prove that Nikon personally insisted in taking Zaporozhian Host 'under the tsar's high hand'. The more power Nikon gained, the better were the chances that Ukraine would receive protection from Moscow.

In May 1649, Alekseǐ Mikhaĭlovich asked Kiev Metropolitan Sylvester Kosiv, for the first time ever, to send to Moscow several educated Ukrainian monks (including the famous Epiphanir Slavinetskiǐ) ${ }^{56}$ It was also the first time that Ukrainian Orthodox professors were involved in Russian Church reforms. Meanwhile, attitudes towards Ukraine were changing very slowly in Moscow. For example, in 1651 Moscow Patriarch Iosif sent his 'opinion' to Zemsky Sobor, while discussions were taking place about the relations with Khmelnytsky. Iosif avoided giving a direct answer - would Ukraine be taken under protection or not - and proposed to rely on 'God's advice'. ${ }^{57}$

In July 1652 Nikon became the new Moscow patriarch. He commenced the new venture with great energy. In April 1653, he had

${ }^{53}$ Boris V. Sapunov, 'Ukrainskaya kniga v Rossii v XVII veke', in Serger P. Luppov, Valentina E. Kutasova et al. (eds.), Istoriya knigi i izdatel'skogo dela. Sbornik nauchnykh trudov (Leningrad, 1977), 8-9.

${ }^{54}$ Plokhil [Plokhy], The Cossacks and Religion, 309, 311.

${ }^{55}$ Kostomarov, Bogdan Khmel'nitskiu, 655.

${ }^{56}$ Kharlampovych, Malorossiǔskoe vliyanie, 120-1.

${ }^{57}$ Guzdenko et al. (eds.), Vossoedinenie, iii, 11-12. 
an official meeting with the Cossack delegation, and blessed them. ${ }^{58}$ In May 1653, Nikon sent a letter to Khmelnytsky, assuring him that he would keep pushing Aleksei Mikhaĭlovich to accept their 'good intention'. ${ }^{59}$ It is not surprising that in August 1653 (when the military situation was quite tense for the Zaporozhian Host), Khmelnytsky appealed directly to Nikon, asking for military support and promising to accept 'the tsar's hand'. ${ }^{60}$ In June 1653, Polish envoys reported from Moscow to the king that the "new patriarch is instigating His Tsarist Majesty to break down the eternal peace with His Majesty... ."61 In the summer of 1653, Polish ambassadors complained that the Moscow patriarch was appointing priests to the churches of the Grand Duchy of Lithuania. They considered this a violation of the Treaty of Polyanovka. ${ }^{62}$

Swedish commissar in Moscow, Johann de Rodes, described the situation at the Muscovite court: "As I was secretly informed, some important persons are very much against this plan [to take Ukraine under protectorate - TT-Y] and try to dissuade his Tsarist Majesty from it ... . The Patriarch calls them cowards and traitors of the Ruthenian faith; it looks like His Tsarist Majesty holds the flagstaff for the patriarch, who is hoisting his banner on it". Rodes also wrote that Khmelnytsky was asking the tsar for protection "only to gain freedom of worship for the Ruthenian religion ... the patriarch considers this to be a reason to start a religious war." 63 And, as Lobachev demonstrated, by 1653 Nikon was not 'giving advice', but rather dictating his will to the tsar.

Alekseĭ Mikhălovich himself acknowledged Nikon's role in decision-making about Ukraine. The tsar's official instructions (nakaz) to the first Kiev voivode stressed religious motives in "taking [Ukraine]

\footnotetext{
58 Ibidem, 267.

${ }^{59}$ Ibidem, 286-7.

${ }^{60}$ Ibidem, 364, 367.

${ }^{61}$ Lev V. Zaborovskiǐ (ed.), Katoliki, pravoslavnye, uniaty: problemy religii $v$ russkopol'skikh otnosheniyakh kontsa 40-kh-80-kh gg. XVII veka: dokumenty, issledovaniya, i: Istochniki vremeni getmanstva B.M. Khmel'nitskogo (Pamiatniki istoricheskor̆ mysli, Moscow, 1998), 126.

62 Ibidem, 137.

${ }^{63}$ Lobachev, Patriarkh Nikon, 137-8. Lobachev used Rodes' original reports, which are currently preserved in the State Archives of Sweden (RA. Muscovitica,
} vol. 600). 
under his hand", and noted: "we consulted with ... His Holiness Patriarch Nikon". ${ }^{64}$ The patriarch also attended the Zemsky Sobor where the historical decision was made. ${ }^{65}$

What was Nikon's goal? Both he and Alekseĭ Mikhaĭlovich were very religious people who believed in their high vocation to improve the Holy Orthodox Church. But Nikon was also a very ambitious man. He was definitely not thinking about "those poor Orthodox people, suffering from the terrible Poles". Nor did he have in mind the 'reunification' of lands and nations of the former Kievan Rus'. He wanted to spread his power into the broad new territories of Ukraine and White Rus' with their many thousand people. He wanted to include the Kievan Metropolitanate in his jurisdiction and, possibly, to become the head of the whole Orthodox world. As we mentioned before, the idea of the 'Third Rome' was very popular among Nikon's entourage.

Some very influential Greek priests supported his ambitions. We have already mentioned patriarch Paisios. In December 1653, the expatriarch of Constantinople, Athanasius, called on Alekseî Mikhailovich to liberate the 'holy city of Constantinople'. ${ }^{66}$ The idea of liberating this holy city from Islam was often popular in Muscovy. In 1688, Tsarevna Sofia even tried to use it to reinforce her power ${ }^{67}$ Reforms to the Muscovite Orthodox Church, started by Nikon, could be seen as an attempt to include his church into the whole Orthodox world.

Nikon made a very aggressive, and successful, start. In September 1654, the Mogilev Episcopate was subordinated to the Moscow Patriarchate. ${ }^{68}$ At the same time Nikon appointed the bishop of Smolensk. Next, the Smolensk and Polotsk Episcopates became subject to the Moscow Patriarchate. ${ }^{69}$ The Muscovite-Polish war was going on very well.

After the Pereyaslav Agreement, Nikon remained constantly and personally involved in Ukrainian affairs. For example, he made the final decision about petitions from Kievan citizens. ${ }^{70}$ The tsar's letter

${ }^{64}$ Zaborovskiı̌ (ed.), Katoliki, pravoslavnye, uniaty, 170; Akty, otnosyashchiesya, x, 353.

${ }^{65}$ Guzdenko et al. (eds.), Vossoedinenie, iii, 406.

66 Vera G. Chentsova, Vostochnaya cerkov' $i$ Rossiya posle Pereyaslavskoŭ rady 1654-1658 (Moscow, 2004), 4.

67 Tatyana Tairova-Yakovleva, Mazepa (Moscow, 2007), 71-2.

${ }^{68}$ Zaborovskiĭ (ed.), Katoliki, pravoslavnye, uniaty, 220.

${ }^{69}$ Kharlampovych, Malorossiǔskoe vliyanie, 170.

${ }^{70}$ Akty, otnosyashchiesya, $\mathrm{x}, 649-51$. 
to the dumny diak (Boyars' Council scribe), when a delegation of Kievan citizens came to Moscow with a petition, is quite characteristic. Alekseĭ Mikhaillovich told him to act "as the Great Sovereign, Most Holy Nikon, patriarch of Moscow and all of Rus' decides". ${ }^{71}$

On the one hand, the Ukrainian clergy was pleased by Nikon. He brought a new, positive attitude towards the Ukrainian Church, its books and theological achievements. After the Time of Troubles, Ukraine was perceived in Moscow as belonging to the different faith and the prohibitions to bring and sell Ukrainian books, introduced by the first Romanov tsar Michael and his father Patriarch Filaret in the 1620s, had been followed by confiscations of Ukrainian books in the borderland regions (see above). Now Nikon in his reforms relied on Ukrainian clergy and their books.

Nevertheless, the Ukrainian clergy became an unexpected and strong obstacle to turning the Metropolitanate of Kiev over to the jurisdiction of the Moscow patriarch. This was especially unexpected if we remember that already in the 1620s Kievan Metropolitan Iov Boretskii had tried to arrange the unification of Kiev with Moscow. ${ }^{72}$ Yet in Boretskiî's days, the situation of the Orthodox Church in Ukraine was tough indeed. By 1654, everything had changed. Even the Polish-Lithuanian Commonwealth was ready for great compromises. Kharlampovych, who studied the position of the Ukrainian clergy, thought that Ukrainians had been afraid of the Muscovite Church, considering it to be uneducated and uncivilised. The Kiev metropolitan was aware of the great governmental control exercised over the Church in Muscovy and of the great dependence of clergy upon the patriarch. Metropolitan Kosov believed that the patriarch of Constantinople would be a much more convenient head of the Ukrainian Church. The behaviour of the newly-appointed bishop of Smolensk only increased those fears. This episcopate had been a part of the Metropolitanate of Kiev. But the new bishop declared war on local church structures and traditions, calling the Smolensk clergy's creed "belonging to different faith". ${ }^{73}$

${ }^{71}$ Akty, otnosyashchiesya, x, 647.

${ }^{72}$ Guzdenko et al. (eds.), Vossoedinenie, i, 46-8. Admittedly, T. Hodana considers Boretskiı̌'s petition to be only an attempt to secure a safe haven in Moscow if the religious situation in Polish-Lithuanian Commonwealth became critical; see Hodana, Między królem i carem, 80.

73 Akty, otnosiashchiesya, vi, 79. 
Years later, the Pereyaslav Agreement turned out to be a major disappointment to both sides. The hetman and his entourage appeared to be very independent and freedom-loving. They did not want to let Muscovite voivodes administer Ukraine; they did not pay taxes and had an independent foreign policy. The same desire to retain their autonomy affected the Ukrainian clergy. Nikon was probably one of few Muscovite leaders who realised the necessity of compromise with Ukraine. Compromise offered the opportunity to retain influence, and even control.

We agree with Kharlampovych that Nikon was quite popular among Ukrainian political elites and some of the clergy. ${ }^{74}$ They appreciated that he was educated and supported Ukrainian theologians and choristers (singers). Both Khmelnytsky and his secretary (the future hetman) Ivan Vyhovsky corresponded with the Moscow patriarch. Faced with strong opposition from the Ukrainian top clergy, Nikon soon gave up the idea of taking the Kievan Metropolitanate under his jurisdiction.

Probably, facing the strong opposition towards his reforms in Muscovy, Nikon wanted to keep Ukrainian clergy as his allies. He did not want, in this situation, to launch a conflict with Greek Patriarchs by altering the subordination of Kievan metropolitan. In this aspect, however, Nikon was opposing Alekseî Mikhaillovich, who insisted on Moscow's right to the consecration of the Kievan metropolitan. Even after the death of the latter in 1657, the Ukrainian hetman and the patriarch of Moscow both preferred to preserve the status quo. Khmelnytsky did not even inform Alekseĭ Mikhaulovich about the metropolitan's death, and arranged the election of the new metropolitan, considering this an internal Ukrainian affair. ${ }^{75}$ The tsar was quite angry due to such behaviour of Khmelnytsky, and Muscovite voivodes expressed their dissatisfaction to the hetman.

Nikon did not want to offend the patriarch of Constantinople by insisting on that consecration. At least, this is how he explained the situation in a letter to Ecumenical Patriarch Dionysius III (1662-5). Nikon confirmed that Kiev and Moscow had used to be one metropolitanate under the Constantinople patriarch, but "over two hundred years ago, they had separated and [Kiev] had come" under the sole

${ }^{74}$ Kharlampovych, Malorossiǔskoe vliyanie, 164-5.

75 Akty, otnosyashchiesya, iv, 8. 
jurisdiction of the patriarch of Constantinople. “... [T] he tsar has told us many times to consecrate the metropolitan of Kiev but I, without your [Dionysius's] blessing, did not want to do this. ..."76

We have seen that Nikon was a key-person in the tsar's decision about the unification between Ukraine and Muscovy. But he also played important role in the separation of Ukraine in 1658. Although the Ukrainian clergy did not want to accept the rule of Moscow patriarch, Ukrainian political elite had a great respect for Nikon. Khmelnytsky called him 'my great master', ${ }^{77}$ while Vyhovsky referred to him as 'our master, father and pastor'. ${ }^{78}$ Hetman Vyhowsky turned to Nikon during the critical aggravation of the Muscovite-Ukrainian relations in January-March 1658. In his conflict with Muscovite voivodes, the hetman tried to address Nikon, asking for support and mediation. ${ }^{79}$ Nikon's disgrace in early summer 1658 became a menacing sign for the Ukrainian elite - right at the moment they were making a choice between Muscovy and the Polish-Lithuanian Commonwealth. Finally, they chose the latter, and in September 1658 signed the Hadiach Agreement with the Polish king. It is worth noting that none of the recent studies by Ukrainian and Polish historians focused on the events of Vyhovsky's hetmanate, addressing the religious factor and the role of Nikon in breaking off the Muscovite-Ukrainian union. ${ }^{80}$

To resume, religious considerations were of utmost importance for Russian Tsar Alekseǐ to take Ukraine 'under his high hand', and Nikon played the key role in this decision.

The years of Nikon's rule were a period of unification between Ukraine and Muscovy. When in 1657 the conflict between the patriarch and the tsar began, it coincided with the beginning of tensions between Kiev and Moscow. But this is another story.

${ }^{76}$ Zapiski otdeleniya, ii, 528.

77 Akty, otnosyashchiesya, xiv, 526-7.

${ }^{78}$ RGADA, F. 196, op. 3, no. 225, 1. 1.

${ }^{79}$ Ivan E. Zabielin (ed.), 'Malorossiřskaya perepiska, khranyashchayasya v archive Moskovskoĭ oruzheĭnoĭ Palaty...', CHOIDR, iii, 8 (1848), 70; RGADA, F. 196 , op. 3, no. 225, 1. 1-2.

${ }^{80}$ Piotr Kroll, Od ugody Hadziackiej do Cudnowa. Kozaczyzna między Rzeczapospolita a Moskwa w latach 1658-1660 (Warsaw, 2008); Viktor Horobets, Elita kozayskŏ Ukrayiny $v$ poshukakh politychnoı̆ legitimatsiyi: stosunki z Moskvoyu ta Varshavoyu (Kiev, 2001). 